\title{
Evaluation of Various Mango Varieties against the Infection Dynamics of Powdery Mildew (Oidium mangiferae Bert.)
}

\author{
Syed Atif Hasan Naqvi1, Rashida Perveen ${ }^{1}$, Syed Amir Manzoor ${ }^{2}$, \\ Hafiz Muhammad Imran Umar ${ }^{3}$, Muhammad Tayyab Iqbal ${ }^{3}$, Fatima Liaquat ${ }^{4}$, \\ Taha Majid1, Ahsan Irshad ${ }^{3}$ \\ ${ }^{1}$ Department of Plant Pathology, FAST, Bahauddin Zakariya University, Multan, Pakistan \\ ${ }^{2}$ Department of Forestry, FAST, Bahauddin Zakariya University, Multan, Pakistan \\ ${ }^{3}$ Department of Plant Breeding \& Genetics, FAST, Bahauddin Zakariya University, Multan, Pakistan \\ ${ }^{4}$ Department of Soil Science, FAST, Bahauddin Zakariya University, Multan, Pakistan \\ Email: ${ }^{*}$ amir.kzd@gmail.com
}

Received 6 May 2014; revised 8 June 2014; accepted 5 July 2014

Copyright (C) 2014 by authors and Scientific Research Publishing Inc.

This work is licensed under the Creative Commons Attribution International License (CC BY).

http://creativecommons.org/licenses/by/4.0/

c) (i) Open Access

\section{Abstract}

Mango (Mangifera indica L: Anacardiaceae) is regarded as the most liked fruit in tropical and subtropical regions of the world. Powdery mildew of mango caused by Oidium mangiferae Bert. is one of the major plant pathological constraints in growing healthy mango orchards. The apparent symptoms of the disease occurred on young tissues of all parts of flowers, leaves and fruits. Severe blossom infection could result in complete damage to fruit; flower failed to open and drop off from the inflorescence. The inflorescence revealed a pattern of disease from tip to downward and showed itself by the emergence of wefts of white mycelium on the affected parts. Twenty-five mango varieties i.e. Langra, Dusehri, Ratole No.12, Fajri, Sindhri, Chaunsa Samar Bahisht, Anwar ratole, Neelam, Yakta, Tota Pari, Sensation, Saroli, Malda, Ghulab e Khas, Chaunsa Black, Chaunsa white, Anmol, Almas, Shan e Ali, Shan e Mustafa, Mahmood Khan, Armughan, Zafaran, Malda Late and Early Gold were evaluated through the observation of symptoms on young inflorescence to determine the disease incidence, disease severity index and average yield of fruit. The study was carried out in a randomized compete block design with twenty-five treatments and three replications. The mango varieties presented different performance in relation to powdery mildew incidence and could be categorized into eight groups. Maximum disease incidence was observed (33.33\%, 26.66\% and 26.66\%, 26.66\%) on Dusehri, Chaunsa Samar Bahisht, Malda and Ratole No.12 respectively and minimum disease incidence was $(3.66 \%$ and $3.66 \%)$ noted on Almas and Sensation. These two varieties showed to be tolerant against the disease. It might be concluded that the presence or absence of symptoms caused by the powdery mildew had no such effect on the fruit yield of the mango cultivars.

${ }^{*}$ Corresponding author.

How to cite this paper: Naqvi, S.A.H., Perveen, R., Manzoor, S.A., Umar, H.M.I., Iqbal, M.T., Liaquat, F., Majid, T. and Irshad, A. (2014) Evaluation of Various Mango Varieties against the Infection Dynamics of Powdery Mildew (Oidium mangiferae Bert.). American Journal of Plant Sciences, 5, 2372-2377. http://dx.doi.org/10.4236/ajps.2014.515250 


\section{Keywords}

\section{Powdery Mildew, Oidium mangiferae Bert., Infection, Varieties, RCBD}

\section{Introduction}

Mango (Mangifera indica L.) is considered the king of fruit among tropical and subtropical regions of the world. In Pakistan, mango is cultivated on an area of 167.5 thousands hectares with the average production of 1732 thousand tones [1]. Mango is vulnerable to various diseases and disorders at all the stages of its augmentation from the nursery to the fruiting plants; which are the cause of its low production [2] [3]. All plant parts of the mango viz. stem, branches, twigs, leaves, petioles, blossoms and fruits are attacked by a number of pathogens. Powdery mildew of mango was present in Indo-Pak sub-continent before 1874 [4]. In Pakistan, disease emerged as a major limiting factor of mango production and the higher input costs have increased the economic importance of the disease. At present, mango orchards are facing a crucial problem of powdery mildew, caused by a fungus Oidium mangiferae Bert., a biotrophic parasite which lives and develops on the host plant tissues. Heavy losses are caused by this disease varying from $10 \%-25 \%$. The spread of the disease mainly depends on the weather conditions which facilitate the disease to proliferate among the orchards [5]. The pathogen survives in old leaves at plant or on the ground during the unfavorable conditions, where the conidia are produced and will cause infection on other leaves, blossoms and fruits. The disease is characterized by the symptoms of white superficial powdery mycelium on inflorescence, leaves and young fruits [6]. The pathogen primarily affects the inflorescence resulted in premature shedding of the flowers and the young fruit before achieving pea size [7] [8]. The disease symptoms appeared in February and March, and the pathogen attacked on flower scales flower heads, young leaves stalks and fruits [9]. The study of the epidemiology and perpetuation of mango powdery mildew [10] showed that the fungus causes maximum infection on the host plant at $26^{\circ} \mathrm{C}$ and $100 \%$ relative humidity. However, the fungus may cause the disease at $15^{\circ} \mathrm{C}$ to $32^{\circ} \mathrm{C}$ and $15.5 \%$ to $100 \%$ relative humidity. The atmospheric temperature was found to be the most important factor responsible for the onset of disease and its epidemic development under natural conditions. It was also observed that the relative humidity ranging from (65\% $-78 \%)$ and a range of minimum temperature from $11^{\circ} \mathrm{C}-14^{\circ} \mathrm{C}$ to a maximum temperature $\left(30^{\circ} \mathrm{C}-40^{\circ} \mathrm{C}\right)$ were noted to be favorable for the onset of mango powdery mildew infection. Resistance to the mango powdery mildew has been investigated in several countries by the researchers but no resistance has been found so far among the mango varieties. All the commercial varieties were found to be susceptible to powdery mildew of mango depending on the climatic factors [11]. The evaluation of mango varieties showed no commercial variety to be resistant against the mango powdery mildew [12]. The screening of eleven mango varieties against the mango powdery mildew showed no variety to be resistant against the disease [13]. Hence, the present study was conducted to determine the cultivar susceptibility, disease severity index and disease incidence percentage and average produce of each variety against the powdery mildew infection.

\section{Materials and Methods}

\subsection{Study Area}

The study was conducted in (February-March) 2011 at the Bhatti Mango Farm in Faiz Pur Bhattian, located $\left(30.270^{\circ} \mathrm{N}\right.$ and $71.250^{\circ} \mathrm{E}, 122 \mathrm{~m}$ altitude from sea level) in the mango zone of Punjab i.e. Multan with a collection of various mango varieties. In general twenty five mango varieties viz. Langra, Dusehri, Ratole No.12, Fajri, Sindhri, Chaunsa Samar Bahisht, Anwar Ratole, Neelam, Yakta, Tota Pari, Sensation, Saroli, Malda, Ghulab e Khas, Chaunsa Black, Chaunsa White, Anmol, Almas, Shan e Ali, Shan e Mustafa, Mahmood Khan, Armughan, Zafaran, Malda Late and Early Gold were assessed. The orchard was well administered by following the conventional cultural practices.

\subsection{Disease Incidence}

The most obvious symptoms of mango powdery mildew were white superficial powdery mycelium on inflorescence, leaves and young fruits. The infection of Powdery mildew was evaluated to determine the disease inci- 
dence percentage and diseases severity index by modifying the scale for anthracnose on inflorescence for the field experiments [13] [14]. For the comparison of yield among the varieties, the number of fruits per variety was calculated at the time of harvesting.

$$
\begin{gathered}
\text { Disease incidence }(\%)=\frac{\text { No. of infected inflorescence }}{\text { Total No. of inflorescence }} \times 100 \\
\text { Disease severity index }=\frac{\text { Sum of all the score of individual inflorescence }}{\text { Total No. of inflorescence observed }} \times \frac{100}{\text { Maximum scale }}
\end{gathered}
$$

Scale for powdery mildew of mango.

\begin{tabular}{ccc}
\hline Score & Visual observation & Response \\
\hline 0 & No infection & Resistant \\
1 & $0.1 \%-7.0 \%$ & Tolerant \\
2 & $7.1 \%-15.0 \%$ & Moderately susceptible \\
3 & $15.1 \%-25.0 \%$ & Susceptible \\
4 & $25.1 \%-100.0 \%$ & Highly susceptible \\
\hline
\end{tabular}

\subsection{Experimental Design}

Powdery mildew was evaluated in 26/02/2011 by the visual observations of symptoms on the young flowers. The experiment was conducted in a randomized complete block design (RCBD); comprising of twenty five treatments and three replications. Ten inflorescence per plant served as one replication. The disease severity index and the average produce of the three plants of each variety were evaluated at the time of maturity i.e. harvesting of the crop in the month of June and July by the statistical analysis.

\subsection{Statistical Analysis}

Data regarding disease severity index of all the varieties and average fruit yield of each variety was subjected to statistical analysis using the analysis of variance (ANOVA). Treatments means were compared by the Duncan New Multiple Range test (DMRT) at $(\mathrm{P} \leq 0.05)$ via SAS (Statistical Analysis System, version 9.1). Incidence data, i.e. the percentage of inflorescence with powdery mildew, were transformed before analysis using the angular transformation (i.e. arcsine of the square root of the percentage) when required.

\section{Results}

The results with reference to the powdery mildew of mango on flowers indicated that almost all the varieties were susceptible to the powdery mildew and showed a varying degree of infection percentage (Table 1). There was no variety found to be resistant against the disease. The pathogen attacks primarily on the flowers. Maximum disease incidence was observed (33.33\%, 26.66\% and 26.66\%, 26.66\%) on Dusehri, Chaunsa Samar Bahisht, Malda and Ratole No.12 respectively and minimum disease incidence was (3.66\% and 3.66\%) noted on Almas and Sensation. Disease severity index showed maximum infection on Dusehri followed by Chaunsa Samar Bahisht, Ratole No.12, Fajri, Sindhri and Malda respectively.

\section{Discussion}

Powdery mildew has become more common and important disease in most of the mango growing areas of the world [15] [16]. The causal organism of the disease is a fungus Oidium mangiferae Berthet. The telemorph stage of this organism is still unknown. The specific symptoms of the disease occurred on young tissues of the all parts of flowers, leaves and fruits. Acute blossom infection may cause complete damage to fruit, flower remains closed and drop from the inflorescence. Almost all the inflorescence showed a pattern of disease from tip to downward and reveals itself by the development of wefts of white mycelium on the infested parts [9] [16]. The results of the experiment showed that the almost all the varieties were susceptible to the disease. Keeping in view the disease 
Table 1. Powdery mildew incidence, severity and fruit yield in mango varieties.

\begin{tabular}{|c|c|c|c|c|}
\hline Varieties & $\begin{array}{l}\text { Powdery mildew* incidence } \\
\text { percentage/3 plants }\end{array}$ & $\begin{array}{l}\text { Powdery mildew severity index } \\
\text { on selected variety }\end{array}$ & Response & $\begin{array}{l}\text { Yield average fruit/ } \\
3 \text { plants }\end{array}$ \\
\hline Langra & $16.66(3.33,23.66)$ & $4.93^{\mathrm{ab}}$ & $S$ & $171^{\mathrm{abc}}$ \\
\hline Dusehri & $33.33(6.66,46.66)$ & $6.89^{\mathrm{a}}$ & HS & $180^{\mathrm{ab}}$ \\
\hline Ratole No.12 & $26.66(11.66,36.66)$ & $6.80^{\mathrm{a}}$ & HS & $189^{\mathrm{ab}}$ \\
\hline Fajri & $23.33(6.66,33.33)$ & $6.12^{\mathrm{ab}}$ & $\mathrm{S}$ & $158^{\mathrm{abc}}$ \\
\hline Sindhri & $23.33(3.33,26.66)$ & $6.55^{\mathrm{ab}}$ & $S$ & $147^{\mathrm{abcd}}$ \\
\hline Chounsa Samar Bahisht & $26.66(11.66,33.33)$ & $6.69^{\mathrm{ab}}$ & HS & $189^{\mathrm{ab}}$ \\
\hline Anwar Ratole & $6.66(3.33,23.66)$ & $4.92^{\mathrm{ab}}$ & $\mathrm{T}$ & $168^{\mathrm{abc}}$ \\
\hline Neelam & $6.66(3.33,18.33)$ & $5.89^{\mathrm{ab}}$ & $\mathrm{T}$ & $178^{\mathrm{ab}}$ \\
\hline Yakta & $6.66(0.00,11.66)$ & $4.11^{\mathrm{ab}}$ & $\mathrm{T}$ & $148^{\mathrm{abcd}}$ \\
\hline Totapari & $11.66(6.66,33.33)$ & $5.68^{\mathrm{ab}}$ & MS & $174^{\mathrm{abc}}$ \\
\hline Sensation & $3.66(3.33,26.66)$ & $3.93^{\mathrm{ab}}$ & $\mathrm{T}$ & $132^{\text {bcd }}$ \\
\hline Saroli & $16.66(11.66,36.66)$ & $5.07^{\mathrm{ab}}$ & S & $162^{\mathrm{abc}}$ \\
\hline Malda & $26.66(3.33,43.66)$ & $6.11^{\mathrm{ab}}$ & HS & $151^{\mathrm{abcd}}$ \\
\hline Gulab e Khas & $11.66(0,23.66)$ & $4.93^{\mathrm{ab}}$ & MS & $159^{\mathrm{abc}}$ \\
\hline Chaunsa Black & $6.66(0,11.66)$ & $4.73^{\mathrm{ab}}$ & $\mathrm{T}$ & $159^{\mathrm{abc}}$ \\
\hline Chaunsa White & $11.66(0,23.66)$ & $3.48^{\mathrm{ab}}$ & MS & $156^{\mathrm{abc}}$ \\
\hline Anmol & $6.66(0.00,11.66)$ & $5.48^{\mathrm{ab}}$ & $\mathrm{T}$ & $143^{\mathrm{abcd}}$ \\
\hline Almas & $3.66(3.33,26.66)$ & $3.70^{\mathrm{ab}}$ & $\mathrm{T}$ & $196^{\mathrm{a}}$ \\
\hline Shan e Ali & $6.66(0,11.66)$ & $3.73^{\mathrm{ab}}$ & $\mathrm{T}$ & $152^{\mathrm{abcd}}$ \\
\hline Shan e Mustafa & $13.33(3.33,26.66)$ & $5.11^{\mathrm{ab}}$ & MS & $155^{\mathrm{abc}}$ \\
\hline Mahmood Khan & $13.33(3.33,21.66)$ & $5.14^{\mathrm{ab}}$ & MS & $170^{\mathrm{abc}}$ \\
\hline Armughan & $6.66(0,11.66)$ & $4.93^{\mathrm{ab}}$ & $\mathrm{T}$ & $92^{\mathrm{d}}$ \\
\hline Zafaran & $16.66(6.66,26.66)$ & $5.37^{\mathrm{ab}}$ & $\mathrm{S}$ & $113^{\mathrm{cd}}$ \\
\hline Malda Late & $16.66(3.33,23.66)$ & $5.37^{\mathrm{ab}}$ & $S$ & $193^{\mathrm{ab}}$ \\
\hline Early Gold & $16.66(3.33,23.66)$ & $5.89^{\mathrm{ab}}$ & S & $140^{\mathrm{abcd}}$ \\
\hline
\end{tabular}

Averages followed by the same letter in severity index and yield of fruit column do not differ statistically from each other $(\mathrm{P} \leq 0.05), \mathrm{SE}=0.72,16.05$. $\mathrm{T}=$ tolerant, $\mathrm{S}=$ susceptible, $\mathrm{MS}$ = moderately susceptible, HS = highly susceptible. ${ }^{*}$ Average incidence (minimum incidence, maximum incidence).

incidence percentage, the varieties showed eight different infection levels. In the first group, Dusehri was present with the maximum infection (33.33\%). In the second group, Chaunsa Samar Bahisht and Ratole No.12 were present with the infestation of (26.66\%). The third group included Fajri and Sindhri showed the infection level (23.33\%). Similarly, in the next one were Langra, Saroli, Zafaran, Malda late and Early gold with (16.66\%) infection. The two varieties Shan e Mustafa and Mahmood Khan showed (13.33\%) infestation followed by Totapari, Ghulab e Khas and Chaunsa white with (11.66\%) infection of the disease. Besides these, Armughan, Shan e Ali, Anmol, Yakta, Neelam, Anwar Ratole and Chaunsa Black showed (6.66\%) infestation of the disease. The minimum disease incidence percentage was observed (3.33\%) in Sensation and Almas. The varieties in eight groups were statistically similar. No variety was resistant to disease yet most of them showed a significant level of tolerance against the disease. Sensation and Almas presented low incidence value and they could be considered as resistant to the disease. The results of the disease severity index showed that there were two 
groups $(A, A B)$ in which means were not statistically different. Maximum disease severity index was observed on Dusehri, Ratole No.12, Fajri, Sindhri, Chaunsa Samar Bahisht and Malda. Some varieties showed lowest disease severity index were Shan e Ali, Shan e Mustafa, Chaunsa White, Sensation, Ghulab e Khas and Armughan. The average number of fruit per tree significantly differed among all the varieties in five dissimilar groups in which the means were similar statistically ranging from 196 fruits (Almas) to 92 fruits (Armughan). The average (maximum) temperature during this experiment before the estimation of powdery mildew infection lingered around $25.6^{\circ} \mathrm{C}$ to $31.2^{\circ} \mathrm{C}$ whereas minimum temperature was recorded $11.2^{\circ} \mathrm{C}$ to $20.0^{\circ} \mathrm{C}$. Precipitation was scarce during the assessment of disease while the last rainfall of $3.1 \mathrm{~mm}$ was recorded before the thirteen days of disease evaluation. On the whole, the atmospheric conditions were completely in favour of the disease by the fungus during the experiment as observed by [10]. Although some varieties showed a higher degree of powdery mildew infection yet, had a considerable yield; they could be considered as tolerant varieties. Rather the disease incidence was very high yet the fruit drop was not significant and a good yield was attained. The study provides useful information about the powdery mildew infection in mango orchards and served as a guide for future field experiments.

\section{Conclusion}

The various mango cultivars showed varying response in relation to the infection of powdery mildew. There was no variety found to be resistant against the disease although they attained significant yield. It might be concluded that the presence or absence of symptoms caused by the powdery mildew had no such effect on the fruit yield of the mango cultivars.

\section{Acknowledgements}

Grateful acknowledgements are to Mr. Muhammad Tariq Malik, Assistant Plant Pathologist at Mango Research Institute, Multan, and the owners of Bhatti Mango Farm for facilitating us to conduct this work.

\section{References}

[1] Balal, R.M., Khan, M.M., Shahid, M.A. and Waqas, M. (2011) Mango Cultivation in Pakistan. Institute of Horticultural Sciences, University of Agriculture, Faisalabad.

[2] Ploetz, R.C., David, B. and Schaffer, B. (1996) A Re-Examination of Mango Decline in Florida. Plant Diseases, 80, 664-668. http://dx.doi.org/10.1094/PD-80-0664

[3] Talpur, M.A. and Khuhro, R.D. (2003) Relative Population of Mango Hopper Species on Different Mango Varieties. Journal of Asia-Pacific Entomology, 6, 183-186. http://dx.doi.org/10.1016/S1226-8615(08)60184-3

[4] Johnson, G.I. (1994) Powdery Mildew. In: Ploetz, R.C., Ed., Compendium of Tropical Fruit Diseases, American Phytopathological Society, St. Paul, 38-39.

[5] Rawal, R.D. and Saxana, A.K. (1997) Diseases of Dryland Horticulture and Their Management. In: Silver Jubilee National Symposium Arid Horticulture, HISAR Proceedings, HSH/CCS, Hisar, HAU, 5-7.

[6] Junqueira, N.T.V., Mda, M. and Ramos, V.H.V. (2001) Doencas da mangueira. In: Manica, I., Eds., Manga Technologia, producao, agroindustria e exportacao, Editora Cinco Continents, Porto Alegre, 361-417.

[7] Parkash, O. (1996) Principal Diseases of Mango: Causes and Control. In: Singh, S.J., Ed., Advances in Diseases of Fruit Crops in India, Kalyani Publisher, India, 191-225.

[8] Misra, A.K. (2002) Integrated Disease Management in Mango. Manual of Summer School on Recent Advances in Production, Protection and Post Harvest Management of Subtropical Fruits.

[9] Singh, L.B. (1960) The Mango Botany, Cultivation and Utilization. Inter-Science Publication Inc., New York.

[10] Gupta, J.H. (1989) Perpetuation and Epidemiology of Powdery Mildew of Mango. Actahorticulturae, Leuven, 231, 528-533.

[11] Akhtar, K.P., Khan, M.A., Kazmi, M.R., Hussain, R.I. and Fatima, B. (1999) Preventive Control of Powdery Mildew Disease of Mango. Agricultural Sciences. Sultan Qaboos University. Journal of Scientometric Research, 4, 23-28.

[12] Ribeiro, I.J.A. (1997) Doencas da mangueira (Mnagifer aindica L.). In: Kimati, H., et al., Eds., Manual de Fitopatologia Volume 2: Doencas das plantascultivadas, 3rd Edition, Agronomica Ceres, Sao Paulo, 511-524.

[13] Carvalho, C.R.L., Rossetto, C.J., Mantovani, D.M.B., Morgano, M.A., De Castro, J.V. and Bortoletto, N. (2004) Avaliacao de cultivares de mangueria selecionadas pelo Instituto Agronomico de Campinas comparadas a outras de impor- 
tanica comerical. Revista Brasileria de Fruticultura, Jaboticabal, 26, 264-271.

[14] Jamadar, M. and Desai, S.A. (1997) Bioefficacy of Dimethomorph against Downy Mildew of Grapevine. Advances of Agriculture Research in India, 4, 81-85.

[15] Verma, K.S. and Deepraj, K. (1998) Management of Powdery Mildew of Mango. Plant Disease Research, 13, 190192.

[16] Palti, J., Pinkas, Y. and Chorin, M. (1974) Powdery Mildew of Mango. Plant Disease Report, 58, 45-49. 
Scientific Research Publishing (SCIRP) is one of the largest Open Access journal publishers. It is currently publishing more than 200 open access, online, peer-reviewed journals covering a wide range of academic disciplines. SCIRP serves the worldwide academic communities and contributes to the progress and application of science with its publication.

Other selected journals from SCIRP are listed as below. Submit your manuscript to us via either submit@scirp.org or Online Submission Portal.
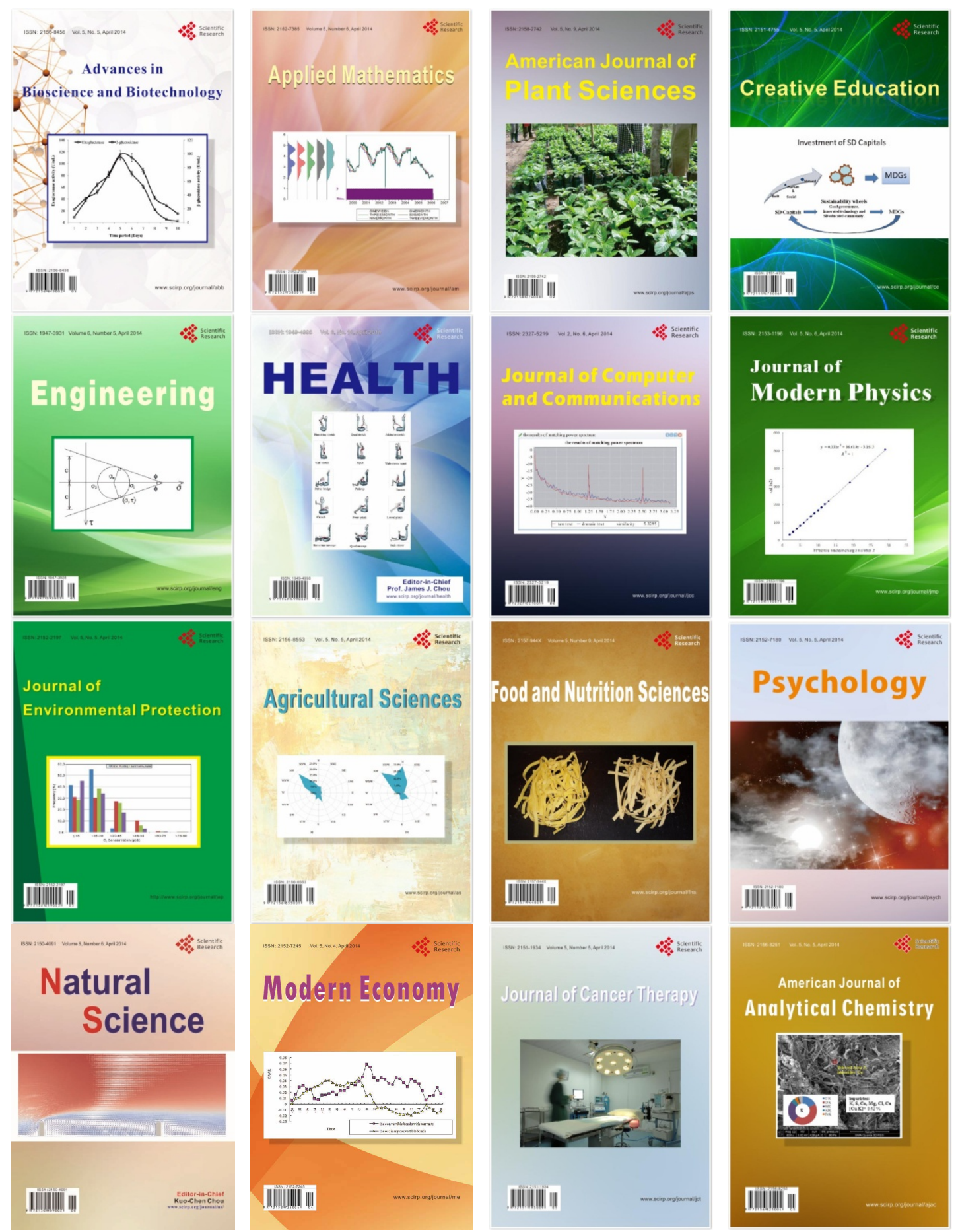